\title{
Transitional Law and Democracy: late responsibility for torture and other atrocities that ocurred in brazilian Military Coup
}

\author{
Direito de Transição e Democracia: responsabilidade tardia pela tortura e \\ outras atrocidades ocorridas na Ditadura Militar brasileira
}

\author{
Mauro Benente ${ }^{1}$ \\ Irene Patricia Nohara ${ }^{2}$ \\ Silvio Luiz Almeida ${ }^{2}$ \\ ${ }^{1}$ Faculdade de Direito de Buenos Aires, Buenos Aires, Argentina \\ ${ }^{2}$ Universidade Presbiteriana Mackenzie, São Paulo, SP, Brasil
}

\begin{abstract}
The main purpose of this study is to focus on the consequences of torture and other atrocities occurred during the Brazilian military coup. Through hypothetical-deductive and inductive methods, it aims to expose the decision of the Supreme Court concerning the Amnesty Law, international condemnation of Brazil in Araguaia case and the responsibility of the State for the death and disappearance of the bodies, including lack of transparency, which are significant worries about transitional law rules. It concerns not only the past, but also has prospective effects, as taking the state oppression out of invisibility contributes to the consolidation of democracy.
\end{abstract}

Keywords: Transitional Law. Democracy. Brazilian Military Coup.
Resumo: O principal objetivo do presente estudo é analisar as consequências da tortura e de outras atrocidades ocorridas no Brasil na ditadura militar. Por meio do emprego dos métodos hipotético-dedutivo e indutivo, procura-se expor a decisão do Supremo Tribunal Federal no tocante à extensão interpretativa da Lei de Anistia, a condenação internacional do Brasil no caso Araguaia, diante das mortes e do desaparecimento forçado de corpos, incluindo a falta de transparência, sendo essas as preocupações da Justiça de Transição. Trata-se de assunto que diz respeito não apenas ao passado, mas que tem efeitos prospectivos, pois trazer da invisibilidade o tema da opressão estatal é uma medida que contribui para a consolidação da democracia.

Palavras-chave: Justiça de Transição. Democracia. Ditadura Militar Brasileira.

Recebido em: 17/07/2019

Revisado em: 23/07/2020

Aprovado em: 27/07/2020

Direito autoral e licença de uso: Este artigo está licenciado sob uma Licença Creative Commons.Com essa licença você pode compartilhar, adaptar, para qualquer fim, desde que atribua a autoria da obra, forneça um link para a licença, e indicar se foram feitas alterações. 


\section{Introduction}

Until recent times, there was the tendency of denying reparation to those persecuted and tortured in "the cellars" of the Brazilian dictatorship (1964 to 1985). The argument used by the judiciary internal system was the prescription of the claim, based on the terms established by a public law from 1932, which determined a five-year period of time to sue the State. Few of the tortured people were able to sue the State in this limited period of time, particularly due to the existing context. Fear strongly marked their "open scars" in view of the permanent repression policy in effect. The Amnesty Law (Public Act 6683, from 1979) was imposed by a "slow, gradual and safe" democratic transition.

The amnesty discourse was arbitrarily imposed since it aimed to include "both sides". It embraced people that were condemned for political crimes, as well as those exiled and also the persecuted by the repressive government, who are actually the ones that should be benefited by amnesty measures, but also tried to cover the agents that handled the repressive system and perpetrated crimes against humanity.

That was part of a political agreement between transitional civilian forces, which did not embrace all sectors of society, and the Armed Forces. They managed to put an end to the problem by editing the mentioned Amnesty Law. However, it was not an adequate solution, as Brazil had signed, with the United Nations, prior to the repression, some human rights treaties which did not allow for prescription of crimes against humanity.

The Second Chamber of the Superior Court of Justice decided (2 T., Min. Fux, Resp 529804-PR, REsp 379414 PR 2001/0152521-2, Rel Min. José Delgado, j. 25.11.2002, STJ) that this kind of offense in fundamental rights does not subsume to the prescriptive terms of the Decree n. 20.910, from 1932, nor to the Civil Code. Then, such claims were considered imprescriptible. It represented an official recognition that the state must indemnify the damage caused by torture and persecution even after the limited period of time established by internal legislation since these were severe crimes committed against human dignity. 
That precedent brought new hopes, as it allowed for a broad discussion, in the area of justice, of a contained litigation, turning the original and authoritative idea of pacifying by blind, which actually means the imposition of oblivion, into the right of repair and respect for individual and collective memory.

The position of the STJ was an option much more coherent with the choice of a democratic state, which in the third part of the first article of its Constitution, considers human dignity as a foundation of the Federal Republic of Brazil, and refuses to ignore that, under the patronage of state, human beings have suffered the most cruel torture due to their different political views towards the need of a democratic government. Those who survive carry up the undeniable consequences of a time that they cannot forget.

Nevertheless, the correct way to remove from "underground history" (as for the torture that occurred in the "cellars" of Brazilian dictatorship) individuals and social groups that experienced state terrorism is by transparency and openness to public debate. This will be able to create a collective memory capable of recognizing and questioning the perverse side that an authoritative state can manifest in this way putting light on the "[...] great dilemma which confronts people in Latin America: the choice between dictatorship or democracy and, further, between alienation or historical identity" (ANSARA, 2008, p. 31).

\section{Indemnity of Torture in Dictatorship and the Problem of Prescription: security in conflict with full responsibility}

The debate of legal certainty is the main problem involving the non-prescription of claims of compensation for torture suffered during the dictatorship. In the Brazilian internal system of justice there was a tendency to recognize the right of such compensation, but it was not possible to seek the criminal culpability of state agents involved in the commitment of these crimes, since the claim was considered invalid due to prescription. 
However, if the government is willing to pay for the indemnity, the logical consequence should be the possibility of charging the agents who caused the damage. The so called "regressive action" is pedagogic, since it avoids the public finances to suffer an unfair cutback caused by an act of a state agent. If such act is at the same time considered a crime, there will be the need of recognizing the criminal responsibility of the agents involved.

Responsibility is the logical consequence of the rule of law, which comprises the submission of the State itself. To be responsible means to be accountable for having caused damage to someone and it involves the corresponding obligation to repair the harm caused. The dictatorship considered itself a State of Emergency, since it resulted from a Coup d'Etat, which occurred in March, 1964. After changing the Constitution, in 1967, the military government also started to create institutional acts that suppressed political and civilian human rights. The institutional act $\mathrm{n}^{\circ} 5$ was the most repressive of them.

Conservative sectors of Brazilian society, specially the ones that supported the military coup, consider that the discussion of the issue is a revenge imposed on them by "leftists". In their view, this so called revenge will disturb the objective of a "safe" and "pacific" transition to democracy.

The first fact indicating a State of Emergency, should be taken into consideration but it must not be seen as an obstacle to international protection of human rights. There are rules determined by the United Nations established to the process of transition from dictatorship to democracy and they do not allow any internal legislation that prevent the agents that perpetrated crimes against humanity from being responsible. Due to this international system of transitional law, incorporated into treaties, some countries of Latin America (as Chile and Argentina) invalidated their arbitrary Amnesty Law.

The second argument, however, is unsustainable. First of all, there was no wide discussion of the model of transition which resulted from the Amnesty Law. It was, in fact, forcefully imposed to society. The Amnesty Law was not a product of a consensus as the social movements were 
brutally repressed and weakened by the government policy of monitoring. Thousands of hundreds of militants, journalists, members of the Church and students were repressed in the precedent decades.

Thus, the image of a gradual, firm and peaceful transition was actually an arbitrary construction. In fact, there was a requirement of "silence", "concealment" and "forced oblivion" of the traumatic experience. Teotonio Vilela, who conducted the works of the Amnesty Law, reported that it was clear that the Amnesty Public Act was imposed by a mechanism of emptying the sections on the Congress and systematic rejection of the proposals of MDB party, which was not discussed (ZELIC, 2010).

The description of what occurred demonstrates that the discussion of Amnesty was not a reality, not even in Congress. So, the presupposed consensus was not true, particularly in a context in which there wasn't support of the institutional environment, as there was actually not a democratic atmosphere.

The discussion of what happened and the recognition of responsibility of people involved in such crimes against humanity is not simply an act of revenge, since pacification with forced oblivion does not mean justice. According to Zelic $(2010$, p. 2): "[...] peace is a product of justice, not of oblivion". In the same direction, argues Celso Antônio Bandeira de Mello. According to him, the recognition of truth about the dictatorship is not just an act of "revenge", but a desire to have those who caused harm to be held responsible within the "most elementary sense of justice" (Manifests of jurists: debate about the reach of amnesty law).

The movement to rescue the truth about crimes perpetrated against humanity during the Brazilian dictatorship is quite recent in the history of the country, but is a very important action, since democracy cannot be consolidated on authoritative grounds. A phrase, said by the ex-Human Rights Secretary, Vannuchi, expresses this felling: without cleaning up the story, that is to say: "without washing the open scars, they will never heal...". 
To demonstrate that rescuing the truth will not harm the consolidation of democracy, it is important to mention the research conducted by Kathryn Sikkink, professor of Political Science at the University of Minnesota. She demonstrated with an expressive sample of one hundred countries that moved from dictatorships to democracy, that the ones which took effective measures to judge crimes, involving torture, murder and prison without process, forced disappearance and genocide, had significant improvement in respecting basic human rights.

It is strange that in recent times on a judicial proceeding tried by federal prosecutors, the State, instead of defending the educational punishment of those who had exceeded in their military tasks and perpetrated crimes against human rights, defended that they could no longer be charged. This is a position considered by Fabio Konder Comparato and Maria Victoria Benevides (2008, p. 3), as "ethically unacceptable", because it disrespects the Constitution and also the treaties that Brazil had signed, even before the Constitution.

One cannot deny that the State's position was totally without logic. It expresses a kind of distorted logic. However, considering the fact that the dictatorship was not caused exclusively by sadist agents who abused their means of repression, one must admit that it has a much more complex background. Despite not having a statute that formally allowed torture, the practice of torture was part of the repressive policy which was not only stimulated, but also sponsored by the government (MAGALHÃES, 1997). The State provided institutional means, torture training and public resources to fund repressive measures.

According to Magalhães, torture was transformed into a scientific method, carefully planned, and used as a way to obtain information about activities or individuals considered national enemies. It therefore involved a "[...] complex system used against subversion and aimed to suppress any suspicious activity considered potentially disruptive of the existing order" (MAGALHÃES, 1997).

Taking into account the context experienced, torture was not only a way to extract information, but it was also used to demobilize and intimidate any kind of reunion or questioning of those who dared 
to discuss the illegitimacy of military regime. Therefore, it was able to constrain not only the individual, but the whole group of people that the authoritative government would like to let know of its enormous capability of cruelty.

Some state agencies received orders to continue the repressive policy. In our opinion, however, that does not prevent the agents who tortured to answer for the harm they caused. The fact is that the dictatorship's safety policies represented an opportunity for personal sadistic manifestations and for the appearance of measures above all that the human mind can conceive as means used to ensure "national security".

However, that was not the understanding of the Brazilian Supreme Court. In a judgment dated August $6^{\text {th }}$., 2010, the high Court decided (ADI 153) that the scope of the Amnesty Law could not be changed, and Brazilian Supreme Court lost the opportunity of reinforcing its commitment to the international human rights protection system, as was recommended by the United Nations.

\section{Right to Truth Against Secret Files}

The transitional process in Brazil was conducted by some politicians who usually say that it was a gradual process. The process was in fact carefully conducted in order to maintain in secret the damage caused by those who made use of the repression apparatus in order to torture. There was no intention of condemning the excesses, since the amnesty law tried to cover up the abuses committed by state agents.

Nevertheless, a democratic government requires that state operations be known by the people, except for public security measures that, according to Norberto Bobbio (2000, p. 20), must be known when the danger ceases. It is forbidden that a democratic state keep public secrets indefinitely hidden. 
Bobbio argues, therefore, that in a democratic environment there should be a maximum period of secrecy, after which the information must be accessible to all. In his words:

[...] the public character is the rule, secrecy, the exception; yet, it must be an exception that does not reduce the force of the rule, since the secret only justifies being kept for a limited period of time and this feature is not different from any of the other measures taken under exception. (BOBBIO, 2000, p. 20)

The solution adopted by the Brazilian Constitution of 1988 was not different, as the XXXIII item of the fifth article determines that:

[...] everybody has the right to receive, from public agencies, information of particular and collective interest, which will be given in terms established by statute, subject to responsibility, except those whose secrecy is indispensable for the security of society and of the State.

The indispensable secrecy for the security of society and State, as Weichert (2007, p. 77) explains is that whose disclosure would possibly cause damage or precipitation of military defense measures or harm business strategies or intelligence police. In the context of maximum effectiveness of fundamental human rights, the State must demonstrate that the secret is necessary to avoid damages. It is not recommended that supposed risks be transformed into an excuse for not providing public documents.

Maintaining secret should not be used as a way to preserve the individual rights of authorities or to hide from society facts about its past, based solely on the presumption that they can be harmful to authorities' biographies. The damage must be current and based on public/collective interests. It is to say that its disclosure must evolve present risks.

Within a reasonable interpretation, the fundamental right of information is the rule, while maintaining secret is an exception (ALEXY, 2002, p. 83). Accordingly, secrecy while relevant to the security of 
society and State covers a restrictive clause, that should also preserve the essential core of the information.

The full access to information about the abuses of dictatorship is a reality which is just recently being stimulated in Brazilian history. With the election of the President Dilma Rousseff, the government took some important measures in benefit of the issue. A Truth Commission was created and a much more developed Information Public Act/Law (12.527/2011) passed (SALGADO, 2019, p. 23).

The access to documents once considered secret data is now allowed: (1.1) This gives families of those dead the right of a proper burial and of the disappeared to know the circumstances of their death. During the dictatorship period, according to Weichert (2007, p. 17), "[...] the political opponent was kidnapped, isolated, murdered, and his mortal remains disappeared or he was buried as indigent [...]"; (1.2) the right of Brazilian society to know what happened in its recent history; and (2) indirectly, the consolidation of democracy, as the absence of truth prevents citizenship conscience and action.

Understanding the truth has effects on the development of civil and political rights. The impact on citizenship contributes to the improvement of public institutions, in order to adjust them to a culture of fundamental respect to rights. Weichert $(2007$, p. 19) concludes that "[...] opening the files means not only understanding the past, but it has prospective effects".

The claim aims to repair and simultaneously rescue the truth, grounded in the presupposition that transparency and public discussion about historical facts provoke political maturity. The openness to selfcritic, with all the uneasiness it can cause, is a much more dignifying medicine in the treatment of human rights violation, compared with hiding and forcing the oblivion in order to maintain impunity. One hard fact that Brazil is facing nowadays is the fact that there are people that deny the violent side of the military regime, and also desires that the present government be transformed into dictatorship. 


\section{Torture as a Method of Persecution and Political Repression}

Brazilian dictatorship was carefully planned. It was built as a "repression apparatus, under the National Security Doctrine" (ARNS, 1985 , p. 17), which was influenced by the international context of the Cold War and was adopted in Brazil by the Superior School of War. The National Security Doctrine was the official ideology of the Armed Forces after the Coup d'Etat. It was influenced by the idea of hunting an internal enemy, by the creation of agencies and regulations about security.

According to research made by Cardinal Arns (1985, p. 72), stated in his well-known report called Brazil: never more, and based on the processes that occurred in Brazilian Military Justice:

The Armed Forces prepared themselves seriously to fight any threat to the authoritative regime imposed by force. However, much more important than the use of an open-war apparatus was the development of a "silent-war" apparatus operating at the interrogative level which included secret investigations, phone listening/interception, storage and processing of information about alleged opposition activities from clandestine forms of opposition against the dictatorship until simple vindication of better salary conditions or of request for more democracy. The National Service of Information (SNI, in Portuguese), created in June, 1964 and, headed by the National Security Council, was developed to ensure the National Security Doctrine. Carlos Fico (2004, p. 38) explains that the creation of the SNI, was made:

Initially with modest purposes compared with the objectives assumed in 1967, when from producing information to support some presidential decisions, it was transformed, under the command of Emílio G. Médici, into the head of a wide net of espionage.

With the expedition of Institutional Act n. 5, espionage became part of the activities of the "hard line" military. SNI was maintained with the task of producing information, but it was not involved directly with the execution of "security operations" - an euphemism for "actions including 
arrests, interrogations, torture and killings" (FICO, 2004, p. 35) - which were carried out by other agencies and by regional security departments.

DOI-CODI was an abbreviation for Information Post on Operations of the Center of Internal Defense. It was one of the main places where those who were considered opponents of the dictatorship were tortured. It was created on January, 1970, by Bandeirantes Operation, an operation which took place in 1969 to combat left army organizations. Each state of the federation had its own DOI, but they were all subject to a single command held by the Armed Forces and also members of the Military and Civil Police.

Provided with budget allocations, the DOI-CODIes led a movement of political repression and were accused of systematic violation of Human Rights. It is also important to mention that according to the content of the complaints made, stated in the report Brazil: never more (1985), the DEOPS (Departments of Social and Politic Order) in Sao Paulo tortured and murdered with almost the same intensity as the DOI-CODI.

Therefore, it is possible to conclude that torture in the Brazilian dictatorship did not occur scarcely or without planning. It was in fact a scientific method which was even included in the curriculum of the military career. The training courses consisted not only of lectures, but also practical classes of torture with people being used as experiments.

That occurred, for instance, with a 24 year-student (Brazil: never more, 1985 , p. 31) who was obliged to serve as experiment in a military facility in Rio de Janeiro. She was naked and beaten in front of twenty officials. In the torture session, she was submitted to electric-chock, hanged by the knees on a stick to be hit upside down, which is a method of torture called, "macaw stick" in Brazil. When the practical demonstration of torture finished, she was taken to a cell and treated by a doctor in order to be useful for other demonstrative classes.

Torture had the specific objective of creating in those arrested the "[...] supreme contradiction between soul and body, by affecting vulnerable points" (LANGGUTH, 1979, p. 32). As said before, it was not 
an accidental product of some sadistic military men. It was, actually, the consequence of a carefully planned policy, carried out by state agencies.

This policy was capable of affecting the social tissue. It affected not only its direct victims, but also their families and descendants. Sometimes the victims received advice from their lawyers or family to remain silent, even during Justice interrogations, because there was a risk that if they told the judges what had happened the security repressive police would capture and torture them again.

Nevertheless, there were people who dared tell about the barbaric actions, the ways in which the police tortured people, the methods employed, the places and the medical presence and complicity, and also the name of the torturers. They have their story recorded in the processes conducted by Military Courts, and demonstrated that torture was not an exception in the Brazilian dictatorship from 1964 to 1979 (1985, p. 282).

Marionilde Dias Brepohl de Magalhães (1997) explains that torture in that context was transformed into a scientific method, which was carefully planned with the objective of obtaining information about activities and individuals considered internal enemies of the nation. By using torture it was possible for government to eliminate many resistance leaders and potential opponents, and to continue its activities without having the compromise of strengthening its bonds with society. Torture was also accompanied by policy control, vigilance and espionage.

\section{Irreversible Damage to the Human Psique}

Torture, according to Alfredo Guillermo Martin (2005, p. 434), is a limit-experience that traumatizes in stages. The psychological effects don't disappear as time goes by and sometimes instead of appearing immediately after the event, they emerge reinforced years later. The experience of torture, under a subjective point of view, means loss of the social support required by a regular functioning of the psyche. The terror experienced in such process always leaves sequelae. 
The most frequent consequences of torture are: cephalic damages, loss of knowledge, cephalic infections, headaches, and organic weakness, loss of weight, anorexia, stomachaches, diarrhea, body aches, bruises, sexual difficulties and respiratory diseases. Also the number of hospitalizations increases in the tortured population. Due to the sophisticated methods of torture employed, developed in order avoid leaving "evidences", it is not always possible to determine their consequences based exclusively on physical injuries. Yet, there are some injuries that appear after many years, although they have stayed asymptomatic for a long period of time.

The psychological consequences, according to Martin Viñar (1989), are caused not only by torture itself, but depend on the method employed, the sequence, or even on what was said during the torture sessions. There was the case of an Argentinean torturer who used to say, during these sessions that the victims would not remain sane. The consequences also depend on the symbolical meaning attributed to the fact, as it usually means institutional complicity and social renouncement, especially due to the oblivion imposition.

The most frequent psychological consequences are: identity problems, dissociative feeling, regressive behavior, non-elaborated grief, chronic anxiety, depression, persistent insomnia, recurrent nightmares, repetition, neurotic disorder and psychotic, irritability, crises of incarceration, feelings of persecution, guilt and shame, isolation, memory disorders and permanent state of alert. These problems often reflect on the social integration of the person and also decrease the ability to work.

The level of psychosis is five times higher in tortured people, and the level of suicides is 16 to $23 \%$ higher. One example was Frei Tito who, even after being released from jail, commited suicide by hanging himself in France, in August 10, 1974, when he was 28 years old. Research points out that the second and third generation of those who suffered torture in Uruguayan dictatorship also were affected by it, which means that torture has a transgenerational effect.

It is important that countries recognizing the right of full indemnity for consequences of torture during the dictatorship; consider 
in their judicial system the effects of torture in a person's physical and psychological health. According to Viñar, it is also important to take into account the individual history of a victim, in the consideration of the points of his/her psyche that was "crushed", as torture provoke specific kinds of traumas.

It is an experience which changes the destiny of the victim. It definitely breaks the human being from his or her subjectivity (VIÑAR, 1989, p. 170). Therefore, it is relevant that the judicial system be aware of the psychological damages of torture, before starting to judge the causes. The judicial system should be aware that even after the release of many tortured people, there were no immediate conditions for their recovery from the traumatic events, since the monitoring policy sponsored by repressive agencies contributed to maintain them in a state of "permanent alert". The experience was not only imaginary. There was still a true threat that remained during the "slow and gradual" transition to democracy.

\section{Torture as a Crime Against Humanity and International Protection of Human Rights}

Marcel Viñar notes that one of the main characteristics of torture is that it is an experience that always changes ones destiny. Those tortured present themselves as a testimony of a wound concerning all of humanity. Their injured bodies are always a symbol (VIÑAR, 1989, p. 164) of what Robert Antelme called "[...] the sense of belonging to the human species".

Torture is a crime so assaulting to the honor and integrity of human beings that when someone is tortured, we can consider that in that exact moment, there is a cultural, ideological and political disruption. Humanity as a whole is violated by this attack on human dignity, something that everybody, without exception, possesses.

In Brazilian legislation this is classified as a hideous crime. According to the international human rights system, when torture is inflicted by a state policy of persecution and extermination of groups, 
due to ethnic, religious or political reasons, it reaches the status of crime against humanity. Within this context it cannot be regarded simply as a political offense, liable of receiving amnesty. All members of humanity are potentially interested on the judgment of these crimes, as they are crimes that involve violence against mankind.

André de Carvalho Ramos exposes that one of the characteristics extracted from international protection of human rights is its universality. Human Rights are universal, "[...] because their holders are human beings, without distinction of religion, gender, political orientation, race, nationality, among others" (RAMOS, 2005, p. 179).

The universality of human rights derives from equality, as it takes into account that every human being has the same value. Thus, it is possible to unveil the network of beliefs and social representations, which, over centuries, sustained mistaken theories which claimed a "natural dominance over each other" (ANSARA, 2008, p. 41).

Human dignity has an essential core extracted from Methaphysics of Moral/Kant (SARLET, 2006, p. 33), as he assumes that no human being can be treated/used as an object. Human dignity is a juridical principle and also a value that must be recognized to all, as long as any member of mankind, without exception, is unique.

The essence of human dignity, therefore, means that human beings exists as an "end in themselves", never as a medium for an arbitrary use of any will. Everybody is irreplaceable and absolutely unique. Therefore, there is a deep debt to the Brazilian students, journalists, militants, community leaders who were jailed, tortured, beaten and murdered by an arbitrary government in its manifestation of sadism, coldness and indifference.

The protection of human dignity is granted in item III of the first article of the Brazilian Constitution, considered the central core of the Federal Republic based on a Democratic Rule of Law. Human dignity is not only seen as a task of the State, but also as a limit to its actions.

It is outrageous that a State, created to protect human beings, be transformed into an apparatus for exterminating, monitoring and torturing 
a group of people. It is also not adequate, according to the International System of Human Rights Protection, that an arbitrary amnesty law be created aiming to protect all those involved from full accountability in the judiciary system.

Since 1945, when Brazil jointed the United Nations, it undertook the international compromise to avoid any suffering to mankind and to respect fundamental human rights. Yet, it has internalized, by a Decree of 1991, the Convention against Torture and other Cruel, Inhuman or Degrading treatment. Brazil has the obligation to respect International System of Human Rights Protection, as it has signed dozens of treaties, including the one which recognized the jurisdiction of the Inter-American Court of Human Rights. The Court has a consolidated orientation that doesn't allow for the establishment of an internal amnesty legislation encompassing crimes against the humanity, specially the legislation that was created in Latin American military dictatorships.

According to Marlon Alberto Weichert (2007), there is no excuse for impunity and that is the reason why the Chilean State was convicted for its omission regarding crimes committed under the Pinochet dictatorship. The possibility of convicting a State based on the international system of human rights protection is a way to force an effective compromise to avoid the open wound that results from the continuous violation of international law. André de Carvalho Ramos (2005) explains that it is due to the system of international responsibility that universal rights can be protected and the State condemned in order to repair the damage caused.

Transitional Justice is used by United Nations and Inter-American Court of Human Rights, and it encompasses four basic values: (1) production of truth, because one cannot deny the right to know about one's own history: which includes access to files, transparency and open discussion; (2) responsibility: including the fact that there is no granted impunity for crimes against humanity; (3) reparation to victims and their families; and (4) institutional reforms in order to modify the mentality of the security mechanism and of the Armed Forces so as to avoid the occurrence of the same mistakes. 
Although the internal decision of the Brazilian Supreme Court did not fully harmonize with the international system of Transitional Law, taking into account the decision of the ADPF n. 153 (about the extension of the Amnesty Law in which the Brazilian Supreme Court decided that the Amnesty Law prohibits the persecution of public agents who tortured), there was a significant condemnation of Brazil in the Inter-American Court of Human Rights. But the previous Brazilian government took two important steps towards the right to memory: it established a Commission of Truth and changed the legislation that dealt with access to information, providing much larger transparency and access to the files which were for a long time kept secret from Brazilian people.

\section{Conclusions}

Brazil had recently discussed the model of transitional law to be adopted. In spite of the decision of the Supreme Court (ADPF 153), from 2010, which accepted the argument of prescription for crimes committed, the country was condemned, in Araguaian case, by Inter-American Court of Human Rights for its omission. It took part of the policies once adopted: opening the secret files and allowing access to information. The creation of a Truth Commission tried to allow for open discussion of crimes against humanity, like murder, torture and persecution during the dictatorship.

Thus there is still hope that once the country obeys, the international system of human rights protection, as other do, removing from "the underground of history" individuals and social groups that experienced state terrorism, this will provoke a broad discussion in the area of justice. Instead of the original idea of "pacifying through oblivion" adopting the right to repair and full respect for the individual and collective memory and including the principle of Transitional Law where there is no granted impunity for crimes against humanity.

Since knowing the truth is the first step for thinking about responsibility, it is possible that discussing the issue will have different prospective effects. The facts, once taken out of invisibility, will 
contribute to the consolidation of democracy in Latin America. Actually, the country is divided in its opinion, and lots of people who suffered and knew the truth are nowadays horrified with the support some part of people imply into the reborn of an institutional act 5, whose "spirit" is not actually buried, even in democracy, so as remind us all from an important idea brought into light by Bertold Brecht: "the people which innocently washes their hands, do so in bloody bowls" (die Leute, die ihre Hände in Unchuld waschen, dies in blutigen Schüsseln tun).

\section{References}

ALEXY, Robert. Teoria de los derechos fundamentales. Traducción de Ernesto Garzón Valdés. Madrid: Centro de Estudios Políticos y Constitucionales, 2002.

ANSARA, Soraia. Memória política, repressão e ditadura no Brasil. Curitiba: Juruá, 2008.

ARNS, Paulo Evaristo. Brazil: nerver more. São Paulo: Vozes, 1985.

BOBBIO, N. Bobbio. O futuro da democracia. Rio de Janeiro: Paz e Terra, 2000.

COMPARATO, F. K.; BENEVIDES, M. V. Ditadura. Folha de São Paulo, São Paulo, p. 3, 30 outubro de 2008.

FICO, Carlos. Versões e controvérsias sobre 1964 e a ditadura militar. Rev. Bras. História, [S.l.], p. 38, 2004.

LANGGUTH, J. A face oculta do terror. Rio de Janeiro: Civilização Brasileira, 1979.

MAGALHÃES, M. D. B. A lógica da suspeição: sobre os aparelhos repressivos à época da ditadura militar no Brasil. Rev. Bras. Hist., São Paulo, v. 17, n. 34, 1997.

MANIFESTO DOS JURISTAS: debate sobre o alcance da Lei de Anistia. Disponível em: http:/www.armazemdamemoria.com.br/cdroms/ videotecas/bnm/Eventos/manifesto\%20dos\%Juristas/Manifesto02.htm. Acesso em: 5 jan. 2012. 


\section{RAMOS, A. C. Teoria Geral dos Direitos Humanos na Ordem} internacional. Rio de Janeiro: Renovar, 2005.

SALGADO, Eneida Desiree. Lei de Acesso à Informação. 2. ed. São Paulo: Thomson Reuters, 2019.

SARLET, Ingo Wolfgang. Dignidade da pessoa humana e direitos fundamentais na Constituição Federal de 1988. 4. ed. Porto Alegre: Livraria do Advogado, 2006.

MARTÍN, Alfredo Guilhermo. The psychological sequelae of torture. Psicol. Cienc. Prof., [S.l.], v. 25, n. 3, p. 434-449, set. 2005. MARTÍN, Guilhermo Martín. The sequelae of torture. Psicol. Cienc. Prof., [S.l.], v. 25, n. 3, p. 434-449, set. 2005.

VIÑAR, M. Exil et Torture. Paris: Denoel, 1989.

WEICHERT, M. Arquivos secretos e direito à verdade. Boletim dos Procuradores da República, [S.l.], n. 77, 2007.

ZELIC, Marcelo. Amnesty Act is an outrage at human rights.

Disponível em. https://www.conjur.com.br/2010-fev-13/manter-leianistia-ataque-aos-avancos-direitos-humanos. Acesso em: 13, fev. 2010.

Mauro Benente is a $\mathrm{PhD}$ in Law at the University of Buenos Aires. Full Professor of Philosophy of Law at the National University of José C. Paz. Regular Adjunct Professor of Theory of the State at the Faculty of Law of the Buenos Aires University. Director of the Interdisciplinary Institute for Constitutional Studies at the National University of José C. Paz.

E-mail: mbenente@unpaz.edu.ar

Endereço Profissional: National University of José C. Paz, Universidade de Buenos Aires, Argentina.

https://orcid.org/0000-0002-5111-5540 
Irene Patrícia Nohara is a $\mathrm{PhD}$ in State Law at the Faculty of Law of USP. Researcher at the Political and Economic Law Program at Universidade Presbiteriana Mackenzie. Lawyer.

E-mail: irene.nohara@uol.com.br

Endereço Profissional: Rua da Consolação, n. 930, Consolação, São Paulo, SP. CEP: 01302-907. https://orcid.org/0000-0002-3182-2803

Silvio Luiz de Almeida is a PhD in Law from the Department of Philosophy and General Theory of Law at the University of São Paulo. Master in Political and Economic Law from the Faculty of Law of Universidade Presbiteriana Mackenzie. Graduated in Law from Universidade Presbiteriana Mackenzie and Graduated in Philosophy from Faculty of Philosophy, Letters and Human Sciences at the University os São Paulo. Researcher at the Graduate Program in Political and Economic Law at Universidade Presbiteriana Mackenzie. Professor at the School of Business Administration of São Paulo at Fundação Getúlio Vargas (FGV-EAESP). Mellon Visiting Professor at the Center for Latin American and Caribbean Studies at Duke University (USA). Director of the Luiz Gama Institute. Lawyer.

E-mail: silviovlq@gmail.com

Endereço Profissional: Rua da Consolação, n. 930, Consolação, São Paulo, SP. CEP: 01302-907. https://orcid.org/0000-0003-0990-9707 